\section{Prostacyclin in systemic lupus and anticardiolipin syndrome}

SIR, Antiphospholipid antibodies (the 'lupus anticoagulant', antibodies to cardiolipin, and antibodies responsible for the biological false positive test for syphilis) have been strongly associated with venous and arterial thrombosis in patients with systemic lupus erythematosus, ${ }^{12}$ according to strict diagnostic criteria proposed by the American Rheumatism Association, ${ }^{3}$ as well as in patients who do not conform to these criteria, termed 'lupus-like' or variant lupus. ${ }^{4}$ Clinical manifestations accompanying the presence of these antibodies have been termed the anticardiolipin syndrome' by Hughes ${ }^{5}$ and included recurrent fetal loss, thrombocytopenia, various neurological abnormalities including stroke, ${ }^{6}$ Guillain-Barré syndrome, ${ }^{7}$ myelopathy, chorea, ${ }^{9}$ and livedo reticularis.

The cause of the thromboses and other features is uncertain. It has been postulated that the antibodies interact with phospholipid in cell membranes of vascular tissue, impairing mobilisation of arachidonic acid and inhibiting production of prostacyclin $\left(\mathrm{PGI}_{2}\right) .{ }^{10}$ It was argued that since $\mathrm{PGI}_{2}$ is a potent vasodilator and inhibitor of platelet aggregation its inhibition might cause a thrombotic state. Carreras et al studied a patient with recurrent arterial thromboses and intrauterine death. ${ }^{10}$ The serum IgG fraction containing the "lupus anticoagulant' reduced the release of $\mathrm{PGI}_{2}$ from rat aortic rings, pregnant human myometrium, and cultured endothelial cells. The inhibition was abolished by arachidonic acid. An inhibitory effect of lupus anticoagulant on $\mathrm{PGI}_{2}$ synthesis in vitro has been confirmed. ${ }^{11} 12$ It has been found, however, that in severe atherosclerosis, where there is also reduced $\mathrm{PGI}_{2}$ synthesis by vascular tissue in vitro, ${ }^{13}$ there is increased $\mathrm{PGI}_{2}$ synthesis in vivo. ${ }^{14}$ The only evidence of reduced

Table 1 Measurement of anticardiolipin antibodies

\begin{tabular}{|c|c|c|}
\hline $\begin{array}{l}\text { Patient } \\
\text { No }\end{array}$ & Anticardiolipin antibody titre & $\begin{array}{l}\text { Plasma } \\
\text { 6-oxo-PGF }(\mathrm{pg} / \mathrm{ml})\end{array}$ \\
\hline
\end{tabular}

\begin{tabular}{lccc}
\hline Systemic & lupus erythematosus & with & the anticardiolipin syndrome \\
1 & 247.8 & - & 3.5 \\
2 & 7.5 & - & 6.8 \\
3 & 8 & - & $<1.0$ \\
4 & 50 & - & $<1.0$ \\
5 & 11.8 & - & $<1.0$ \\
6 & 300 & - & $<1.0$ \\
7 & 50 & - & $<1.0$ \\
8 & 15.2 & & 1.5 \\
& & - & \\
Systemic & lupus & erythematosus & without the anticardiolipin syndrome \\
1 & - & - & 1.8 \\
2 & - & - & 2.1 \\
3 & - & - & 2.5 \\
4 & - & - & 2.8 \\
5 & - & & 1.7
\end{tabular}

${ }^{*} \mathrm{GPL}$ units=IgG anticardiolipin antibody titre; MPL units $=\operatorname{lgM}$ anticardiolipin antibody titre.
$\mathrm{PGI}_{2}$ synthesis in vivo in the lupus anticoagulant syndrom was in the case reported by Carreras et al. ${ }^{10}$ in whom the plasma concentration of 6-oxo-PGF ${ }_{1 \mathrm{a}}$, the stable hydrolysis product of $\mathrm{PGI}_{2}$, was fit to be reduced. It has subsequent become evident, however, that radioimmunoassay plasma 6 -oxo-PGF ${ }_{1 \text { a }}$ gives highly inaccurate values. ${ }^{15}$

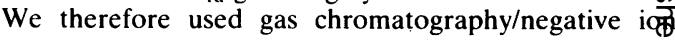
electron capture mass spectrometry (the most sensitive are specific existing method) to determine plasma concentrô, tions of 6-oxo-PGF Ia, $_{\text {in }}$ ingt patients (24-40 years) with anticardiolipin antibodies and a history of recurrent thrombosis, and in five patients (20-35 years) witt systemic lupus erythematosus without this antibody. The anticardiolipin antibodies were measured by a modific tion of the original enzyme linked immunosorbent assay technique $^{16}$ as described by Harris et al and the resula expressed as GPL ( =IgG) or MPL (IgM) units. The resultis are shown in Table 1 . We previously reported that healthy non-pregnant women plasma 6-oxo-PGF ${ }_{1: 1}$ is lese than $3 \mathrm{pg} / \mathrm{ml} .{ }^{17}$ Two of the subjects with anticardiolip? antibodies had plasma concentrations of 6-oxo-PGE $\mathrm{l}_{\mathrm{la}}$ just above this range, i.e., 3.5 and $6.8 \mathrm{pg} / \mathrm{ml}$, but these modes increases are consistent with venous trauma during ven puncture, which was not as easy as in healthy subjects. The remaining results were all normal. It will be of gre interest to determine excretion rates of metabolites of $\mathrm{PGI}_{2}$ and thromboxane in the urine of such patients as am integrated measure of the production rate throughout the body.

Lupus Arthritis Research Unit,

The Rayne Institute,

St Thomas`s Hospital

Department of Clinical Pharmacology,

Royal Postgraduate Medical School of

London, Hammersmith Hospital

R A ASHERSO

E N HARR鱼

G R V HUGHES

$J$ M RITTER

$S$ E BARRO

M JONES

\section{References}

1 Harris E N, Gharavi A E. Boey M L, et al. Anticardiolip? antibodies: detection by radio-immunoassay and association. with thrombosis in systemic lupus erythematosus. Lancet 1988 ii: $1211-4$

2 Vermylen J. Blockmans D. Spitz B, Deckmyn N H. Thrombosi and immune disorder. Clin Haematol 1986; 15: 1-17.

3 Tan E M, Cohen A S. Fries J F, et al. The 1982 revised criteris for the classification of SLE. Arthritis Rheum 1982; 25: 1271-

4 Asherson R A. Chan J K H. Harris E N, Gharavi A E, Hughes: $G R$ V. Clinical and laboratory features associated wiff anticardiolipin antibodics in non-SLE patients [Abstract]. Arthritis Rheum 1985; 28: 77S.

5 Hughes G R V. The anticardiolipin syndrome [Editorial]. Cline Exp Rheumatol 1985; 3: 285-6.

6 Harris E N. Gharavi A E, Asherson R A, Boey M L, Hughe G R V. Cerebral infarction in systemic lupus: association with anticardiolipin antibodies. Clin Exp Rheumatol 1984; 2: 47-5

7 Harris E N, Englert H, Derue G, Hughes G R V, Gharavi AD Antiphospholipid antibodies in acute Guillain-Barré syndrome. Lancet 1983; ii: 1361-2.

8 Oppenheimer S, Hoffbrand B I. Optic neuritis and myelopat in systemic lupus erythematosus. Can J Neurol Sci 1986; 1 \% $129-32$.

9 Asherson R A, Derksen R H W M, Harris E N, et al. Chorea systemic lupus and 'lupus-like' disease. Semin Arthritis Rher (in press) 
10 Carreras L O. Defreyn G. Machin S J. et al. Arterial thrombosis, intrauterine death and 'lupus anticoagulant': detection of immunoglobulin interfering with prostacyclin formation. Lancet 1981: i: 244-6.

11 Marchesi D. Parbtani A. Frampton G. Livio M. Remuzzi G. Cameron J S. Thrombotic tendency in systemic lupus erythematosus. Lancet 1981: i: 719 .

12 Carreras L O, Vermylen J G. 'Lupus' anticoagulant and thrombosis-possible role of inhibition of prostacyclin formation. Thromb Haemost 1982; 48: 38-40.

13 Sinzinger H. Feigl W. Silberbauer K. Prostacyclin generation in atherosclerotic arteries. Lancet 1979: ii: 469.

14 FitzGerald G A. Smith B. Pedersen A K. Brash A R. Increased prostacyclin biosynthesis in patients with severe atherosclerosis and platelet activation. $N$ Engl J Med 1984: 310: 1065-8.

15 Blair I A. Barrow S E. Waddell K A. Lewis P J. Dollery C T. Prostacyclin is not a circulating hormone in man. Prostaglandins 1982: 23: 579-89.

16 Gharavi A E. Harris E N. Asherson R A. Hughes G R V Anticardiolipin antibodies: isotype distribution and phospholipid specificity. Ann Rheum Dis 1987: 46: 1-6.

17 Barrow S E. Blair I A. Waddell K A. Shepherd G L. Lewis P J. Dollery C T. Prostacyclin in late pregnancy: analysis of 6-oxo$\mathrm{PGF}_{1:}$ in maternal plasma. In: Lewis $\mathbf{P} \mathrm{J}$. Moncada S. O'Grady J. eds. Protacyclin in pregnancy. New York: Raven. 1983.

\section{Book reviews}

Clinical Rheumatology. Eds G V Ball, W J Koopman. $£ 39 \cdot 50$. Pp. 356. Saunders: Eastbourne, Sussex. 1986 .

This North American text sets out to present a concise and clinically comprehensive account of current rheumatology, and in this it succeeds very well. The authors virtually all come from the University of Alabama, Birmingham. Possibly because the contributors are so geographically proximate, the book is surprisingly up to date with 1985 references in a 1986 publication. The format is along conventional lines with introductory chapters on relevant basic biological sciences, clinical chapters on defined disorders, and, finally, chapters on regional symptom complexes. An amazing amount of factual information is condensed between the covers, and it is difficult to take exception to the views expressed.

It is, however, a textbook and not a reference book. and thus the chapter references are limited to less than 10. This results in a somewhat uneven feel to the book-sources of data are named in the text but do not appear in the references. It is obvious why this had to be so, as the length of the references would otherwise have exceeded the text. but possibly the authors could allow themselves more latitude in further editions. The perennial problem of the North American compared with European classification of juvenile chronic arthritis emerges. No doubt for reasons of space. little attention is given to evaluation and examination of the musculoskeletal system, and somewhat paradoxically the chapter 'On seeing patients' starts with the subheading "use of the laboratory". Other cultural differences emerge-the commonest cause of a persistently raised uric acid level in patients receiving allopurinol is given as being due to extensive tophi, whereas compliance must be the commonest cause in the UK. Notwithstanding these quibbles. I thoroughly enjoyed the style and content of this book.

The major difficulty is in identifying the market for it in this country. It is too complex for undergraduates and does not contain enough detailed description of patient evaluation for MRCP candidates. Because it is not a reference book it does not replace the monoliths. It would, however, provide a sound and sensible background for any doctor embarking on a registrar or senior registrar post in rheumatology.

Department of Rheumatology,

IAN GRIFFITHS

Royal Victoria Infirmary,

Queen Victoria Road,

Newcastle upon Tyne

Eponyms in Orthopaedics and Rheumatology. By J M H Moll. Wall chart $341 / 2 \times 23$ inches. $£ 5 \cdot 70$. Chapman and Hall: London. 1986.

'That's interesting: where did you get it?'

'That' is a wall chart designed by Dr John Moll. It contains a sketch and brief notes about 42 men who have given their names eponymously to rheumatological or orthopaedic matters, such as syndromes, signs, methods of treatment, or instruments. For each there is also an illustration of the matter to which the eponym refers. Among the portraits I am in a position to judge only one likeness (I heard the subject lecture at the Brighton Congress) and that is excellent.

This is my first success at creating brightness and interest on the walls of my office. I recommend it.

The London Hospital

H L F CURREY

Therapeutics in Rheumatology Eds. $\mathrm{J} \mathrm{M} \mathrm{H} \mathrm{Moll,}$ H A Bird, A Rushton. Pp 539. £45.00. Chapman and Hall: London. 1986.

This book is about the drugs used in the treatment of the rheumatic disorders and to some extent relates their usage to the overall management of the patient. Its stated purpose is to inform rheumatologists generally about the plethora of antirheumatic drugs on the market and to act as a means of updating previous knowledge. It should be said at the outset that it succeeds in its main aims. One of the problems with such a book, however, is the length of time between preparation and actual publication. Inevitably. therefore, some of the information is already out of date, and for instance, one of the drugs suggested as having disease modifying properties has already been withdrawn. Few of the references are later than 1983, and this is an inherent difficulty in disseminating information in this way as a hard back volume. This delay becomes important when one of the stated aims is to act as an update facility.

The book is divided into three sections-pharmacological 